\title{
Chemotherapy with cisplatin and vinorelbine for elderly patients with locally advanced or metastatic non-small-cell lung cancer
} (NSCLC)

\author{
José Rodrigues Pereira*1, Sandro J Martins ${ }^{2,3}$, Sueli M Nikaedo ${ }^{1}$ and \\ Flora K Ikari ${ }^{1}$
}

\begin{abstract}
Address: ${ }^{1}$ Lung Cancer Division, Instituto do Câncer Arnaldo Vieira de Carvalho, R. Martinico Prado 26 cj. 101, 01224-010 São Paulo, Brazil, ${ }^{2}$ Pulmonary Division, University of São Paulo Medical School, Av. Dr. Arnaldo 455, 01246-903 São Paulo, Brazil and ${ }^{3}$ Current address: Oncology Unit, Hospital Santa Izabel, Pca Almeida Couto 500, 40050-410 Salvador, Brazil
\end{abstract}

Email: José Rodrigues Pereira* - joserp@uol.com.br; Sandro J Martins - sjmartins@yahoo.com; Sueli M Nikaedo - joserp@uol.com.br; Flora K Ikari - joserp@uol.com.br

* Corresponding author

Published: 29 September 2004

BMC Cancer 2004, 4:69 doi:10.1 I86/147|-2407-4-69
Received: 0 I August 2003

Accepted: 29 September 2004

This article is available from: http://www.biomedcentral.com/I47I-2407/4/69

(c) 2004 Pereira et al; licensee BioMed Central Ltd.

This is an open-access article distributed under the terms of the Creative Commons Attribution License (http://creativecommons.org/licenses/by/2.0), which permits unrestricted use, distribution, and reproduction in any medium, provided the original work is properly cited.

\begin{abstract}
Background: Although modest improvements in the survival of patients with non-small cell lung cancer (NSCLC) can be achieved with cisplatin-based chemotherapy (CT), its value is disputed in the geriatric setting. In this study, we evaluate the feasibility of vinorelbine/cisplatin CT for elderly NSCLC patients.

Methods: In this pilot phase I/II trial, all patients received CT with vinorelbine $25 \mathrm{mg} / \mathrm{m}^{2}$, on day I and 8 , and cisplatin on day I, in 28 days-cycles. After stratification for age (up to 75 years), younger patients were sequentially allocated to moderate cisplatin doses $\left(80 \mathrm{mg} / \mathrm{m}^{2}\right.$ or $\left.90 \mathrm{mg} / \mathrm{m}^{2}\right)$, and older patients were allocated to lower cisplatin doses $\left(60 \mathrm{mg} / \mathrm{m}^{2}\right.$ or $\left.70 \mathrm{mg} / \mathrm{m}^{2}\right)$. We recruited patients aged over 70 years with newly diagnosed NSCLC, clinical stage III or IV, Karnofsky performance status $\geq 70 \%$, normal serum creatinine, peripheral neuropathy $\leq$ grade I, and no prior cancer therapy.

Results: Analysis was by intention to treat. Main toxicities (grade 3-4) was as follows: neutropenia, $20 \%$; anemia, II\%; and thrombocytopenia, $2 \%$; alopecia, $55 \%$; fatigue, $11 \%$; and peripheral neurotoxicity, 2\%. No grade 3-4 emesis or renal toxicity occurred. Global median time to progression (TTP) and overall survival (OS) were 27.0 (95\% Cl: 10.1 to 43.7$)$ weeks and 30.1 (95\% Cl: 24.4 to 35.8 ) weeks; I- and 2-year survival rates were $36.3 \%$ and $13.2 \%$, respectively. Overall response rate was $50.0 \%$ (95\% Cl: $35.4 \%$ to $64.5 \%$ ), with I complete response; no difference on response rate was noticed according to cisplatin dose. Median overall survival was 30.1 weeks, with $\mathrm{I}$ - and 2 -year survival rates of $36.3 \%$ and $13.2 \%$, respectively.
\end{abstract}

Conclusion: Age does not preclude assessment on the role of cisplatin-vinorelbine CT for elderly NSCLC patients with good performance status and adequate bodily functions. 


\section{Background}

Lung cancer is a disease with a great incidence in older people. In Brazil, its incidence rate in male sex was expected to reach 18.8:100.000 in 1999, and aged patients may have accounted for $57 \%$ of all lung cancer deaths. Unfortunately, up to two thirds will present at diagnosis with advanced disease, requiring chemotherapy (CT) [1].

Vinorelbine, a semi synthetic vinca alkaloid, is a highly active drug for NSCLC and its association with cisplatin is worthwhile. European and Southwest Oncology Group trials demonstrated that vinorelbine/cisplatin (VP) offer therapeutic advantage over both drugs alone [2-4], previous cisplatin-based schedules [3]; comparing to taxane combinations, VP is therapeutically equivalent to carboplatin/paclitaxel [5] or carboplatin/docetaxel [6] but inferior to cisplatin/docetaxel [6].

Although modest improvements in the survival of patients with non-small cell lung cancer (NSCLC) can be achieved with cisplatin-based CT [7], its value is disputed in the geriatric context. The simultaneous presence of several diseases and homeostenosis, an age-related physiologic process that change the way that the body handles drugs, can shift therapeutic index, allowing harm outweigh any survival gain. On the other hand, underdiagnosis and undertreatment of lung cancer in the elderly is a fact, often explained in terms of ageism in medical oncology staff [8] and people's beliefs and fears about the disease and its treatment $[8,9]$. Whether we should treat or not aged patients with cisplatin-based CT surely is an unsolved issue. In this study, we evaluated the feasibleness and activity of vinorelbine/cisplatin CT for elderly NSCLC patients.

\section{Methods}

This study enrolled patients older than 70 years with unresectable locally advanced or metastatic NSCLC. Informed consent was obtained from patients and their relatives, as approved by the Institutional Ethical Committee. Inclusion criteria: all patients had to have histologically confirmed NSCLC; Karnofsky performance status $\geq 70$; measurable disease; adequate bone marrow reserve (neutrophils $\geq 2 \times 10^{9} / \mathrm{L}$ and platelets $\geq 100 \times 10^{9} / \mathrm{L}$ ), bilirubin under 1.25 times upper normal value (UNV), aspartate aminotransferase/alanine aminotransferase (AST/ALT) under 2 times UNV, and renal function (creatinine level under $120 \mu \mathrm{mol} / \mathrm{L}$ ); no symptomatic brain metastasis; no prior cancer therapy; no indication for palliative radiation therapy; no previous or concomitant malignancy; and adequate social support. Exclusion criteria were symptomatic peripheral neuropathy and comorbidity regarded as an impediment for CT, such as renal disease, heart failure, coronary heart disease, uncontrolled infection, and cognitive impairment.
Baseline work up included a medical history and physical examination; whole blood count (WBC) and biochemistry; chest $\mathrm{x}$-ray; bone scintigraphy scan; chest, abdominal and brain computed axial tomography scans; and electrocardiogram. Although pretreatment bone scan and brain CAT scan are recommended only when signs or symptoms of disease are present, they were added here due to Institutional Protocol Reviewers recommendation.

Treatment consisted of vinorelbine $25 \mathrm{mg} / \mathrm{m}^{2}$ on days 1 and 8 , administered intravenously in bolus, followed by intravenous cisplatin over 1 hour. CT was administered every 4 weeks. Prophylactic anti-emetic drugs (intra venous dexamethasone $20 \mathrm{mg}$ and ondansetron $16 \mathrm{mg}$ ) and fluid hydration $\left(0.9 \%\right.$ saline, $1 \mathrm{~L} / \mathrm{m}^{2}$; and magnesium sulfate, $20 \mathrm{mmol}$ ) was used to minimize renal toxicity. Dexamethasone $4 \mathrm{mg}$ PO BID plus metoclopramide 10 mg PO QID for 4 days was used to prevent delayed emesis. Patients were time-sequentially assigned to one of two groups, from lower to higher doses, according to age strata. Study doses were defined based on previous reports on renal tolerance of cisplatin in geriatric patients $[10,11]$. Age stratification was arbitrary. Those aged up to 75 years received cisplatin 60 or $70 \mathrm{mg} / \mathrm{m}^{2}$ and those aged 70 to 75 received cisplatin 80 or $90 \mathrm{mg} / \mathrm{m}^{2}$. Assignation to high dose groups $\left(70 \mathrm{mg} / \mathrm{m}^{2}\right.$ and $\left.90 \mathrm{mg} / \mathrm{m}^{2}\right)$ occurred after evaluation of toxicity at inferior doses, evaluated according to National Cancer Institute criteria. The protocol required a minimum of 6 and a maximum of 18 patients per group after the 1 st cycle for safety analysis.

Chemotherapy doses were reduced for haematological, neurological, hepatic and renal toxicities. Toxicity was graded according to National Cancer Institute (NCI) common toxicity criteria guidelines. Changes in dosage were based on WBC results obtained on day 1 of treatment; if neutrophils were $<1.5 \times 10^{9} / \mathrm{L}$ and platelets were $<100 \times$ $10 \% / \mathrm{L}$, treatment was delayed by 1 week. Treament on days 8 had to be cancelled if neutrophil counts were $<1.0$ $\times 10^{9} / \mathrm{L}$ and platelets were $<100 \times 10^{9} / \mathrm{L}$. If treatment could not be given after a 2 -week interval because of haematological toxicity, it had to be discontinued and the patient withdrawn from the study. Concomitant use of hematopoietic growth factors were not allowed in the first treatment cycle but were administered subsequently on individual basis. Neurological toxicity above grade 2 resulted in suspension of treatment; ototoxicity grade 2 or 3 resulted in a $50 \%$ dose reduction of cisplatin.

The following dose modifications of vinorelbine were set based on AST/ALT (aspartate aminotransferase/alanine aminotransferase) and bilirubin values on day 1 or day 8 of treatment: if AST/ALT were between 5.1 and $20.0 \times$ UNV or bilirubin was between 1.5 and $3.0 \times$ UNV, dosing was cancelled and the patient was reassessed 1 week later. 
If AST/ALT were $>20.0 \times \mathrm{UNV}$ or bilirubin was $>3.0 \times$ $\mathrm{UNV}$, vinorelbine was discontinued. If serum creatinine was grade $>1$, the dose was delayed by 1 week and the test repeated. After a 2 -week delay, the patient was taken off the study. WBC and biochemistry were also performed on day +14 of treatment.

We intended to administer a maximum of four CT cycles followed by radiation therapy in responding patients with stage III disease and six CT cycles in patients with wet IIIB or stage IV disease. Notwithstanding radical radiation therapy (RT) should deliver a total dose down to $66 \mathrm{~Gy}$, covering tumor site and regional lymph nodes, and palliative therapy could use doses under to $45 \mathrm{~Gy}$, the final choice of dose, fractioning, irradiated volume, and energies of radiation was at the radiation oncologist's discretion. Treatment interruption was allowed in case of disease progression, severe adverse events, or patient preference.

Chest $\mathrm{x}$-ray was performed before each cycle, and CAT scans every two cycle for response evaluation. Tumor response was recorded according to World Health Organization criteria and measured by the same observer (JRP). All responses had to be confirmed 3-4 weeks from initial evaluation. We reported here the best response designation recorded from the start of treatment until disease progression. Patients stopping treatment with an unconfirmed response, or only short stabilisation were considered as inevaluable, unless the response or stabilisation was further confirmed in the absence of any treat- ment. Patients were monitored for the first month offstudy then followed up every 2-3 months.

The dose intensity was calculated for both drugs by dividing the actual dose delivered by the length of therapy. Toxic death was defined as death occurring during the chemotherapeutic phase (including four weeks after its end) and due to drug toxicity. Early death was defined as death within four weeks after a chemotherapy cycle without severe toxicity and not related to the malignant disease. Response and survival were calculated by intentionto-treat. Progression was defined in relation to the best response obtained. The time to tumor progression lasted from the first day of treatment to the date of the first observation of progressive disease. Survival was defined as the time elapsed from the beginning of CT until death or last follow-up visit. Time-to-event analysis was performed using the Kaplan-Meier product-limit estimator. All analyses were carried out using a computer program (SPSS version 8.0, Chicago, USA).

\section{Results}

Forty-four patients were recruited from July 1996 to June 1998; twenty-nine aged 70-75 year and fifteen older than 75 years. Cisplatin doses were as follows: in the older cohort, seven patients received $60 \mathrm{mg} / \mathrm{m}^{2}$ and eight received $70 \mathrm{mg} / \mathrm{m}^{2}$; in the former, fifteen patients received $80 \mathrm{mg} / \mathrm{m}^{2}$ and fourteen received $90 \mathrm{mg} / \mathrm{m}^{2}$. Patient characteristics are given in Table 1 . Most of the patients presented stage III disease $(56.8 \%)$ and squamous cell carcinoma (52.3\%).

Table I: Patient characteristics

\begin{tabular}{|c|c|c|c|c|c|}
\hline & \multicolumn{4}{|c|}{ Study Group } & \multirow{3}{*}{$\begin{array}{l}\text { Total } \\
(n=44)\end{array}$} \\
\hline & \multicolumn{2}{|c|}{70 to 75 years } & \multicolumn{2}{|c|}{$>75$ years } & \\
\hline & 80 mg/m2 (n = 15) & 90 mg/m2 (n = 14) & $60 \mathrm{mg} / \mathrm{m} 2(\mathrm{n}=7)$ & 70 mg/m2 (n = 8) & \\
\hline Median age (range, in years) & $73(7 \mid$ to 74$)$ & $73(71$ to 74$)$ & 79 (76 to 84$)$ & 77 (76 to 85$)$ & 74 (7I to 75$)$ \\
\hline \multicolumn{6}{|l|}{ Gender } \\
\hline Male & 12 & 12 & 5 & 5 & $34(77 \%)$ \\
\hline Female & 3 & 2 & 2 & 3 & $10(23 \%)$ \\
\hline \multicolumn{6}{|l|}{ Karnofsky performance status } \\
\hline 70 & 8 & 7 & 4 & 3 & $22(50 \%)$ \\
\hline $80-90$ & 7 & 7 & 3 & 5 & $22(50 \%)$ \\
\hline \multicolumn{6}{|l|}{ Stage: } \\
\hline IIIA & 5 & 1 & - & 2 & $8(18 \%)$ \\
\hline IIIB & 5 & 8 & 3 & 1 & $17(39 \%)$ \\
\hline IV & 5 & 5 & 4 & 5 & $19(43 \%)$ \\
\hline \multicolumn{6}{|l|}{ Histology: } \\
\hline Squamous cell carcinoma & 9 & 5 & 2 & 7 & $23(52 \%)$ \\
\hline Adenocarcinoma & 3 & 7 & 3 & - & $13(30 \%)$ \\
\hline Others & 3 & 2 & 2 & $\mathrm{I}$ & $8(18 \%)$ \\
\hline
\end{tabular}


Table 2: Therapy results

\begin{tabular}{|c|c|c|c|c|c|}
\hline & \multicolumn{4}{|c|}{ Study Group } & \multirow{3}{*}{$\begin{array}{l}\text { Total } \\
(n=44)\end{array}$} \\
\hline & \multicolumn{2}{|c|}{70 to 75 years } & \multicolumn{2}{|c|}{$>75$ years } & \\
\hline & $80 \mathrm{mg} / \mathrm{m} 2(\mathrm{n}=15)$ & $90 \mathrm{mg} / \mathrm{m} 2(\mathrm{n}=14)$ & $60 \mathrm{mg} / \mathrm{m} 2(\mathrm{n}=7)$ & $70 \mathrm{mg} / \mathrm{m} 2(\mathrm{n}=8)$ & \\
\hline \multicolumn{6}{|l|}{ Treatment administered } \\
\hline \multicolumn{6}{|l|}{ Chemotherapy cycles } \\
\hline No. & 46 & 42 & 14 & 23 & 125 \\
\hline Median (range) & $2(1$ to 4$)$ & $2(1$ to 5$)$ & $3(1$ to 5$)$ & $3(1$ to 6$)$ & $3(1$ to 6$)$ \\
\hline Vinorelbine (median, $\mathrm{mg} / \mathrm{m}^{2} / \mathrm{wk}$ ) & 8.6 & 8.8 & 9.4 & 10.3 & 8.9 \\
\hline Cisplatin (median, $\mathrm{mg} / \mathrm{m}^{2} / \mathrm{wk}$ ) & 13.6 & 15.9 & 11.2 & 14.4 & 14.5 \\
\hline \multicolumn{6}{|l|}{ Efficacy } \\
\hline Complete response & - & - & - & I & I \\
\hline Partial response & 8 & 8 & 2 & 3 & 21 \\
\hline Stable disease & 4 & 4 & 3 & 2 & 13 \\
\hline Progressive disease & 2 & I & - & - & 3 \\
\hline Not evaluated & 1 & I & 2 & 2 & 6 \\
\hline Overall response rate (\%) & 53 & 57 & 29 & 50 & 50 \\
\hline Time to progression (median, in weeks) & 25.0 & 23.0 & 15.7 & 18.4 & 27.0 \\
\hline \multicolumn{6}{|l|}{ Overall Survival } \\
\hline Median (weeks) & 31.0 & 17.3 & 26.6 & 31.7 & 30.1 \\
\hline I-year (\%) & 40.0 & 35.7 & 28.5 & 37.5 & 36.3 \\
\hline
\end{tabular}

Treatment results are shown in Table 2. A total of 125 CT cycles were administered and the median was 3 (range: 1 to 6). No difference was noticed on the dose intensity achieved across the four groups (Kruskal-Wallis test, $\mathrm{p}=$ 0.13 ). Objective response could not be evaluated in six patients due to treatment discontinuation before cycle 2 : early death (1), withdrawal of consent (2) and toxicity (3). Twelve out of 25 patients with stage III disease responded to CT and received radical radiation therapy (median delivered dose: $50 \mathrm{~Gy}$; range: $40 \mathrm{~Gy}$ to $66 \mathrm{~Gy}$ ). Fifteen patients $(34.0 \%)$ received maximum allowed CT cycles; excessive toxicity $(\mathrm{n}=8)$, progressive disease $(\mathrm{n}=$ $3)$, progressive disease after initial response $(n=13)$, and patient choice $(\mathrm{n}=5)$ were reasons for protocol withdrawal. At a median follow-up time of 77.2 weeks, six patients were alive. Response rate (RR) was 50.0\% (95\% CI: $35.4 \%$ to $64.5 \%$ ), with 1 complete response. Global median time to progression (TTP) and overall survival (OS) were 27.0 (95\% CI: 10.1 to 43.7 ) weeks and 30.1 (95\% CI: 24.4 to 35.8 ) weeks; 1- and 2-year survival rates were $36.3 \%$ and $13.2 \%$, respectively. No significant difference was noticed in RR ( $p=0.65)$, TTP $(p=0.62)$, and OS $(\mathrm{p}=0.44)$ across study groups. There was no difference according to stage (III vs. IV) in RR $(48 \%$ vs. $53 \%$, p = $0.76)$, ТTP ( 32.6 vs. 25.0 weeks, $\mathrm{p}=0.73$ ), or OS ( 31.7 vs. 28.6 weeks, $\mathrm{p}=0.33$ ). Likewise there was no difference according to age groups ( $70-74$ vs. $\geq 75$ years) in RR (55\% vs. $40 \%, \mathrm{p}=0.34)$, ТTP ( 31.7 vs. 28.6 weeks, $\mathrm{p}=0.33$ ), or OS (30.1 vs. 31.7 weeks, $\mathrm{p}=0.76)$.
Toxicity data are presented in Table 3 . Hematological toxicity (grade 3-4) was as follows: neutropenia, 20\%; anemia, $11 \%$; and thrombocytopenia, 2\%. Common nonhematologic grade 3-4 side effects were alopecia $(18 \%)$ and fatigue (11\%); severe peripheral neurotoxicity occurred in one patient; neither severe emesis nor renal toxicity was noticed. At the highest cisplatin dose $(90 \mathrm{mg} /$ $\mathrm{m} 2$ ) there were two early deaths and one toxic death due to neutropenic sepsis. No case of febrile neutropenia was noticed.

\section{Discussion}

Treatment of elderly NSCLC patients with cisplatin-based regimens has been a less contentious matter nowadays but toxicity remains a major issue. In our pilot study, chemotherapy with cisplatin $70-80 \mathrm{mg} / \mathrm{m}^{2}$ on day 1 plus vinorelbine $25 \mathrm{mg} / \mathrm{m}^{2}$ on days 1 and 8 , repeated each 28 days per in the maximum four cycles, was feasible for elderly NSCLC patients. Neurological and renal tolerance was particularly good. At the time we developed the protocol, no quality-of-life instrument had been validated for use in Brazil. Thus, a drawback in our study is the absence of quality-of-life analysis, which precludes evaluation of key dimensions in geriatric oncology.

Cisplatin induces a sensory neuropathy due to axonal damage that is dependent on the total-dose and singledose intensity [12], and it is also time-dependent [13], making histological lesions more common than clinical toxicity. Although in this trial most patients received mod- 
Table 3: Patient tolerance

\begin{tabular}{|c|c|c|c|c|c|c|c|c|c|c|}
\hline & \multicolumn{4}{|c|}{70 to 75 years } & \multicolumn{4}{|c|}{$>75$ years } & \multirow{3}{*}{$\begin{array}{c}\text { Grade } \\
n\end{array}$} & \multirow[b]{3}{*}{$\%$} \\
\hline & \multicolumn{2}{|c|}{$80 \mathrm{mg} / \mathrm{m} 2$} & \multicolumn{2}{|c|}{$90 \mathrm{mg} / \mathrm{m} 2$} & \multicolumn{2}{|c|}{$60 \mathrm{mg} / \mathrm{m} 2$} & \multicolumn{2}{|c|}{$70 \mathrm{mg} / \mathrm{m} 2$} & & \\
\hline & 3 & 4 & 3 & 4 & 3 & 4 & 3 & 4 & & \\
\hline \multicolumn{11}{|l|}{ Haematological } \\
\hline Neutrophils & 2 & 3 & I & 2 & - & - & 1 & - & 9 & 20 \\
\hline Haemoglobin & 2 & - & 2 & - & - & - & I & - & 5 & 11 \\
\hline Platelets & - & - & - & - & - & - & 1 & - & 1 & 2 \\
\hline \multicolumn{11}{|l|}{ Clinical } \\
\hline Alopecia (grade 2) & \multicolumn{2}{|c|}{ (3) } & \multicolumn{2}{|c|}{$(2)$} & \multicolumn{2}{|c|}{ (I) } & \multicolumn{2}{|c|}{$(2)$} & 8 & 18 \\
\hline Fatigue & I & - & 2 & - & - & - & 1 & - & 4 & 9 \\
\hline Nausea and vomiting & - & - & - & - & - & - & - & - & - & \\
\hline Neurosensory & I & - & - & - & - & - & - & - & 1 & 2 \\
\hline Renal & - & - & - & - & - & - & - & - & - & \\
\hline Infection & - & - & I & - & - & - & - & - & 1 & 2 \\
\hline Early death & \multicolumn{2}{|c|}{-} & \multicolumn{2}{|c|}{2} & \multicolumn{2}{|c|}{-} & \multicolumn{2}{|c|}{-} & 2 & 4 \\
\hline Toxic death & \multicolumn{2}{|c|}{-} & \multicolumn{2}{|c|}{ I } & \multicolumn{2}{|c|}{-} & \multicolumn{2}{|c|}{-} & 1 & 2 \\
\hline
\end{tabular}

erate cisplatin doses, only one had grade 3 peripheral neuropathy. Our data may reflect the low median of cycles actually administered rather than inaccuracy of clinical signs to evidence tissue lesion. Similarly, Ohe et al. [14] delivered a median of three cycle of cisplatin-containing CT and reported no case of severe neuropathy.

Cisplatin renal toxicity has been attributed to drug-protein interactions and the inactivation of specific brush border enzymes, resulting in damage of the loops of Henle, the distal tubules, and collecting ducts. Patients aged above 70 or even 80 are regarded as susceptible to cisplatin-induced renal damage as the younger counterparts $[15,16]$ and current studies have reported a low incidence of renal toxicity in elderly patients [14,17]. No case of severe renal toxicity was noticed in our patients, as estimated by serum creatinine and its clearance (CockroftGault method), but this finding may be artifactual due to small sample sizes, selection bias, and low sensitivity of estimated creatinine clearance to predict actual glomerular filtration rate (GFR) [18].

The observed response rate here was in the usually range of NSCLC phase II trials, but the absence of external review of radiological data and the widened confidence intervals expected because of small sample sizes in each group limit assertions that could otherwise be drawn. The 1 -year survival rate $(36 \%)$ was good but essentially equivalent to the reported elsewhere [19] for vinorelbine alone $(32 \%)$ and inferior to the observed for weekly cisplatindocetaxel (64\%) [14]. Nonetheless, survival figures should be cautiously considered in this underpowered, heterogeneous, non-randomized pilot study.
Vinorelbine is a cytotoxic agent that clearly has expanded the therapeutic options for elderly NSCLC patients $[20,21]$. The next logical step to improve therapeutic indexes was to combine it with other active drugs. Recently, relevant results emerged from European phase III trials addressing the role of novel drugs in the treatment of elderly NSCLC patients [19,22-25]. The Elderly Lung Cancer Vinorelbine Italian Study (ELVIS) [19], interrupted for slow recruitment, evidenced an improvement of some lung cancer-related symptoms (pain and dyspnea), worsening of toxicity-related symptoms (cognitive function, constipation, and peripheral neuropathy), and a limited survival advantage ( 28 vs. 21 weeks) for singleagent vinorelbine as compared to supportive care, a survival gain that resembles the benefit reported by metaanalysis for nowadays considered substandard cisplatinbased regimens in advanced NSCLC.

Although sequential administration of drugs is an attractive option for aged or frail patients, a setting where minimal treatment-related toxicity should be pursued, research on the role of non-platinum combinations for elderly NSCLC patients aroused attention. The Southern Italy Cooperative Oncology Group (SICOG) evaluated whether the association of vinorelbine and gemcitabine would be better than vinorelbine alone. To date, final results of this trial have not to come. Despite an article focusing on the interim analysis of 120 patients (60 at each group) claimed a survival advantage for the combined arm [22], further intent-to-treat analysis including 18 patients more reached a less optimistic conclusion: median survival in the combined and single-agent arms were nearly the same (25 weeks and 23 weeks, respectively) and both values were deemed comparable to the observed in the supportive care arm of the ELVIS (21 
weeks) [23]. Since that at least 152 patients was treated in the SICOG trial [24], a definite report of mature survival data is awaited. In addition, investigators of the Multicenter Italian Lung Cancer in the Elderly Study (MILES) [25] reported no survival benefit for the combination of vinorelbine plus gemcitabine in comparison to singleagent vinorelbine or gemcitabine in the treatment of elderly NSCLC patients.

The question whether or not cisplatin-containing regimens should be used to treat aged patients remains an important, still open, issue. As observed for paclitaxel-carboplatin [26], gemcitabine-cisplatin [27], and docetaxelcisplatin [14] associations, the role of vinorelbine-cisplatin regimens deserve to be investigated. Until the outcome of large clinical trials addressing this issue proves at least the equivalence of newer drug associations to platinumbased regimens, as seems to be true for the combination of paclitaxel and gemcitabine [28], there are few reasons to preclude the evaluation of current combined regimens in the chemotherapy of elderly NSCLC patients with normal bodily functions and good performance status.

\section{Competing interests}

This study was supported by Institutional funds only. Authors did hot received reimbursements, fees, funding, or salary from an organization that may in any way gain or lose financially from the publication of this paper in the past five years.

\section{Abbreviations (order of appearance) \\ NSCLC: non-small cell lung cancerCT: chemotherapy}

NCI: National Cancer Institute

ELVIS: Elderly Lung Cancer Vinorelbine Italian Study

SICOG: Southern Italy Cooperative Oncology Group

GFR: glomerular filtration rate

\section{Authors' contributions}

JRP was responsible for study conception, protocol conduction, and results interpretation. SJM carried out the data analysis and results discussion. SMN and FKI were responsible for patient care and data gathering

\section{Acknowledgements}

The authors are grateful to Dr. Olavo Feher for a critical review of this manuscript.

\section{References}

I. Martins SJ, Pereira JR: Clinical factors and prognosis in nonsmall cell lung cancer. Am J Clin Oncol I999, 22(5):453-457.

2. Depierre A, Chastang C, Quoix E, Lebeau B, Blanchon F, Paillot N, Lemarie E, Milleron B, Moro D, Clavier J, et al.: Vinorelbine versus vinorelbine plus cisplatin in advanced non-small cell lung cancer: a randomized trial. Ann Oncol 1994, 5(I):37-42.

3. Le Chevalier T, Brisgand D, Douillard JY, Pujol JL, Alberola V, Monnier A, Riviere A, Lianes P, Chomy P, Cigolari S, et al: Randomized study of vinorelbine and cisplatin versus vindesine and cisplatin versus vinorelbine alone in advanced non-small-cell lung cancer: results of a European multicenter trial including $\mathbf{6 1 2}$ patients. J Clin Oncol 1994, I2(2):360-367.

4. Wozniak AJ, Crowley JJ, Balcerzak SP, Weiss GR, Spiridonidis CH, Baker LH, Albain KS, Kelly K, Taylor SA, Gandara DR, et al.: Randomized trial comparing cisplatin with cisplatin plus vinorelbine in the treatment of advanced non-small-cell lung cancer: a Southwest Oncology Group study. J Clin Oncol 1998, 16(7):2459-2465.

5. Kelly K, Crowley J, Bunn PA Jr, Presant CA, Grevstad PK, Moinpour CM, Ramsey SD, Wozniak AJ, Weiss GR, Moore DF, et al.: Randomized phase III trial of paclitaxel plus carboplatin versus vinorelbine plus cisplatin in the treatment of patients with advanced non--small-cell lung cancer: a Southwest Oncology Group trial. J Clin Oncol 200I, 19(13):3210-3218.

6. Fossella F, Pereira JR, von Pawel J, Pluzanska A, Gorbounova V, Kaukel E, Mattson KV, Ramlau R, Szczesna A, Fidias P, et al.: Randomized, multinational, phase III study of docetaxel plus platinum combinations versus vinorelbine plus cisplatin for advanced non-small-cell lung cancer: the TAX 326 study group. J Clin Oncol 2003, 2 I ( 16):3016-3024.

7. Chemotherapy in non-small cell lung cancer: a meta-analysis using updated data on individual patients from 52 randomised clinical trials. Non-small Cell Lung Cancer Collaborative Group. Bmj 1995, 31 I (70 10):899-909.

8. Turner NJ, Haward RA, Mulley GP, Selby PJ: Cancer in old age--is it inadequately investigated and treated? $\mathrm{Bmj}$ 1999, 319(7205):309-312.

9. Brown JS, Eraut D, Trask C, Davison AG: Age and the treatment of lung cancer. Thorax 1996, 5 I (6):564-568.

10. Hrushesky W], Shimp W, Kennedy BJ: Lack of age-dependent cisplatin nephrotoxicity. Am J Med I984, 76(4):579-584.

11. Thyss A, Saudes L, Otto J, Creisson A, Gaspard MH, Dassonville O, Schneider M: Renal tolerance of cisplatin in patients more than 80 years old. J Clin Oncol I994, I 2(I0):2 I 2I-2I 25.

12. Cavaletti G, Marzorati L, Bogliun G, Colombo N, Marzola M, Pittelli MR, Tredici G: Cisplatin-induced peripheral neurotoxicity is dependent on total-dose intensity and single-dose intensity. Cancer 1992, 69(1):203-207.

13. Gregg RW, Molepo JM, Monpetit VJ, Mikael NZ, Redmond D, Gadia $M$, Stewart DJ: Cisplatin neurotoxicity: the relationship between dosage, time, and platinum concentration in neurologic tissues, and morphologic evidence of toxicity. J Clin Oncol 1992, 10(5):795-803

14. Ohe Y, Niho S, Kakinuma R, Kubota K, Ohmatsu H, Goto K, Nokihara $H$, Kunitoh $H$, Saijo $N$, Aono $H$, Watanabe $K$, Tango $M$, Yokoyama A, Nishiwaki Y: A phase II study of cisplatin and docetaxel administered as three consecutive weekly infusions for advanced non-small-cell lung cancer in elderly patients. Ann Oncol 2004, I 5(I):45-50.

15. Hrushesky W], Shimp W, Kennedy B]: Lack of age-dependent cisplatin nephrotoxicity. Am J Med I984, 76(4):579-584.

16. Thyss A, Saudes L, Otto J, Creisson A, Gaspard MH, Dassonville O, Schneider M: Renal tolerance of cisplatin in patients more than 80 years old. J Clin Oncol 1994, I 2(10):2I 2 I-2I 25.

17. Kubota K, Furuse K, Kawahara M, Kodama N, Ogawara M, Takada M, Masuda N, Negoro S, Matsui K, Takifuji N, et al:: Cisplatin-based combination chemotherapy for elderly patients with nonsmall-cell lung cancer. Cancer Chemother Pharmacol 1997, 40(6):469-474.

18. Levey AS, Bosch JP, Lewis JB, Greene T, Rogers N, Roth D: A more accurate method to estimate glomerular filtration rate from serum creatinine: a new prediction equation. Modification of Diet in Renal Disease Study Group. Ann Intern Med 1999, I30(6):46|-470.

19. Effects of vinorelbine on quality of life and survival of elderly patients with advanced non-small-cell lung cancer. The Elderly Lung Cancer Vinorelbine Italian Study Group. J Natl Cancer Inst 1999, 9 I (I):66-72.

20. Veronesi A, Crivellari D, Magri MD, Cartei G, Mansutti M, Foladore $S$, Monfardini S: Vinorelbine treatment of advanced non-small 
cell lung cancer with special emphasis on elderly patients. Eur J Cancer 1996, 32A(10): 1809-|8|I.

21. Gridelli C, Perrone F, Gallo C, De Marinis F, lanniello G, Cigolari S, Cariello S, Di Costanzo F, D'Aprile M, Rossi A, et al:: Vinorelbine is well tolerated and active in the treatment of elderly patients with advanced non-small cell lung cancer. A two-stage phase II study. Eur J Cancer 1997, 33(3):392-397.

22. Frasci G, Lorusso V, Panza N, Comella P, Nicolella G, Bianco A, De Cataldis G, lannelli A, Bilancia D, Belli M, et al:: Gemcitabine plus vinorelbine versus vinorelbine alone in elderly patients with advanced non-small-cell lung cancer. J Clin Oncol 2000, I 8(I 3):2529-2536.

23. Frasci G, Lorusso V, Panza N, Comella P, Nicolella G, Bianco A, DeCataldis G, Belli M, lannelli N, Massidda B, et al.: Gemcitabine plus vinorelbine yields better survival outcome than vinorelbine alone in elderly patients with advanced non-small cell lung cancer. A Southern Italy Cooperative Oncology Group (SICOG) phase III trial. Lung Cancer 200I, 34(Suppl 4):S65-69.

24. Frasci G, Lorusso V, Panza N, Comella P, De Cataldis G, Micillo E, lannelli N, Filippelli G, Muci D, Piantedosi FV, et al:: Gemcitabine + vinorelbine (GV) yields better survival than vinorelbine (V) alone in elderly non-small cell lung cancer (NSCLC) patients. Final analysis of a Southern Italy Cooperative Group (SICOG) phase III trial [abstract]. Ann Oncol 2000, I I(Suppl 4): 108.

25. Gridelli C, Perrone F, Gallo C, Cigolari S, Rossi A, Piantedosi F, Barbera S, Ferrau F, Piazza E, Rosetti F, et al:: Chemotherapy for elderly patients with advanced non-small-cell lung cancer: the Multicenter Italian Lung Cancer in the Elderly Study (MILES) phase III randomized trial. J Natl Cancer Inst 2003, 95(5):362-372.

26. Langer CJ, Manola J, Bernardo P, Kugler JW, Bonomi P, Cella D, Johnson $\mathrm{DH}$ : Cisplatin-based therapy for elderly patients with advanced non-small-cell lung cancer: implications of Eastern Cooperative Oncology Group 5592, a randomized trial. J Natl Cancer Inst 2002, 94(3): 173-181.

27. Feliu J, Martin G, Madronal C, Rodriguez-Jaraiz A, Castro J, Rodriguez A, Checa T, Bolano M, Casado E, Gonzalez-Baron M: Combination of low-dose cisplatin and gemcitabine for treatment of elderly patients with advanced non-small-cell lung cancer. Cancer Chemother Pharmacol 2003, 52:247-252.

28. Cardenal F, Lopez-Cabrerizo MP, Anton A, Alberola V, Massuti B, Carrato A, Barneto I, Lomas M, Garcia M, Lianes P, et al.: Randomized phase III study of gemcitabine-cisplatin versus etoposide-cisplatin in the treatment of locally advanced or metastatic non-small-cell lung cancer. J Clin Oncol 1999, 17(I):12-18.

29. Kosmidis P, Mylonakis N, Nicolaides C, Kalophonos C, Samantas E, Boukovinas J, Fountzilas G, Skarlos D, Economopoulos T, Tsavdaridis $D$, et al:: Paclitaxel plus carboplatin versus gemcitabine plus paclitaxel in advanced non-small-cell lung cancer: a phase III randomized trial. J Clin Oncol 2002, 20( I 7):3578-3585.

\section{Pre-publication history}

The pre-publication history for this paper can be accessed here:

http://www.biomedcentral.com/1471-2407/4/69/prepub

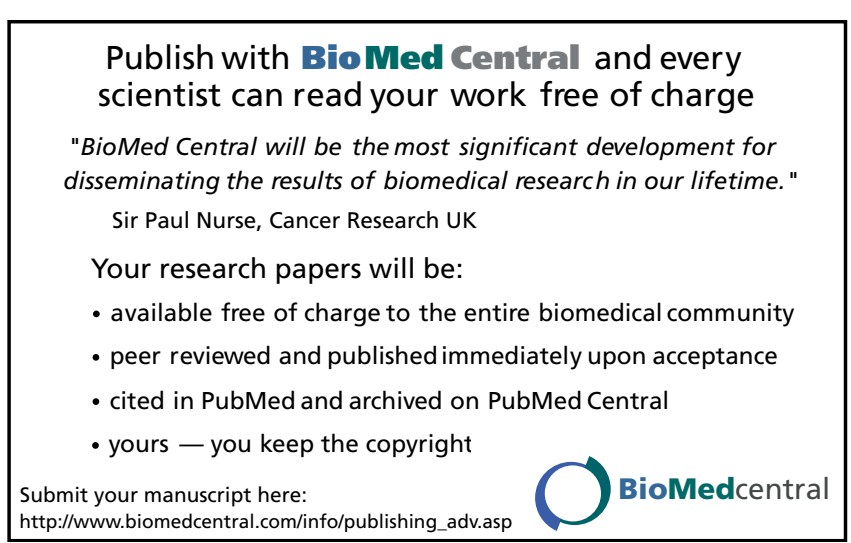

